\title{
OPTIMIZATION STUDIES ON BIOSYNTHESIS OF CITRIC ACID BY ON E-FACTOR-AT-A-TIME
}

\author{
Anand Kishore Kola ${ }^{1}$, Mallaiah Mekala ${ }^{2}{ }^{*}$, Venkat Reddy Goli ${ }^{1}$
}

https://doi.org/10.23939/chcht12.04.511

\begin{abstract}
In the presented study, the significant operating variables regarding biosynthesis of citric acid process were assessed and their effects on the process yield were analysed. These variables, namely, initial sucrose concentration, methanol concentration, inoculum density, initial medium $\mathrm{pH}$, spore age, stirrer speed, incubation period, fermentation temperature, particle size distribution, oxygen flow rate, and moisture content have significant influence on bioprocess of citric acid production. Plackett-Burman approach was used to determine the most significant variables, which predominantly influence the citric acid production process. Out of the eleven variables, initial sucrose concentration, initial medium $\mathrm{pH}$, stirrer speed, incubation period, fermentation temperature, and oxygen flow rate were found to be significant. The effect of the significant variables on the yield of citric acid has been validated experimentally by one-factor-at-a-time empirical optimization technique. The optimum conditions have been determined. The effect of each variable on the yield of citric acid was analysed critically.
\end{abstract}

Key words: citric acid, sucrose, incubation time, fermentation, optimization, one-factor-at-a-time method.

\section{Introduction}

Citric acid is a low toxic organic chemical produced today extensively worldwide by fermentation technology of different microorganisms. The main uses of citric acid are in the food, beverage and pharmaceutical industries as an acidulant. However, because of growing demand for citric acid, the world production of the citric acid by fermentation process is increasing tremendously. In South America, Mexico and Greece, citric acid is still being produced from citrus fruits. However, today almost $99 \%$ production of the citric acid in the world is mainly from microbial process, i.e. by various fermentation processes, substrates and microorganisms. As production

\footnotetext{
${ }^{1}$ Department of Chemical Engineering, National Institute of

Technology, Warangal, 506 004, Telangana, India

${ }^{2}$ Department of Chemical Engineering, BV Raju Institute of

Technology, Narsapur, 502 313, Telangana, India

* mmyadav2001@gmail.com

(C) Kola A., Mekala M., Goli V., 2018
}

of citric acid does not satisfy the required demand, economical and sustainable advanced processes are needed.

Microbial production of citric acid was first noticed by Wehmer [1] by a culture of Penicillium glaucum, where sugar was used as the medium. Industrial cultivations were not successful because of a problem with contaminations and long period of cultivation. The effect of starting sucrose concentration (100-180 g. $\mathrm{l}^{-1}$ ), initial nitrogen concentration $\left(0-0.3 \mathrm{~g} \cdot \mathrm{l}^{-1}\right)$, methanol and ethanol concentration $(0-6 \mathrm{ml})$ in $100 \mathrm{ml}$ feeding medium were studied experimentally by Kursat et al. [2] and the optimum conditions were determined to be as follows: initial sucrose concentration $\left(140 \mathrm{~g} \cdot \mathrm{l}^{-1}\right)$, initial nitrogen concentration $\left(0.05 \mathrm{~g}^{-1} \mathrm{l}^{-1}\right)$, methanol $(4.0 \mathrm{ml})$, and ethanol $(3.0 \mathrm{ml})$ giving maximum citric acid.

Crolla et al. [3] have reported the effects of fermentor agitation and fed-batch mode of operation on citric acid production from Candida lipolitica using $n$ paraffin as the carbon source. An optimum range of agitation speeds $800-1000 \mathrm{rpm}$ corresponding to Reynolds numbers from 50000 to 63000 gave best substrate utilization and biomass growth and citric acid production rates. Three cycle fed-batch system increased the overall production rates of citric acid. Kamzolova et $a l$. [4] have studied the amount of oxygen necessary for the growth of Yarrowia lipolitica and production of citric acid. They observed that the amount of oxygen required for microorganism growth and synthesis of citric acid depends on concentration of iron in the medium. The authors found that at relatively low oxygen content and high iron concentration, citric acid accumulation was $120 \mathrm{~g} \cdot \mathrm{l}^{-1}$, the specific rate of citric acid was $120 \mathrm{mg}$, the mass yield coefficient was 0.87 , and the energy yield coefficient was 0.31 .

Hossain et al. [5] and Xu et al. [6] reported the effect of sugar concentration and the type of carbon source on the production of citric acid. Xu et al. [6] observed optimum yield of citric acid at a sucrose concentration of $10 \%$ and glucose concentration of $7.5 \%$.

Roukas [7] studied the pre-treatment of date syrup with sulphuric acid, tricalcium phosphate, hydrochloric acid, potassium ferrocyanide, and EDTA to increase citric acid production. They observed that $2 \%$ tricalcium 
phosphate gave citric acid concentration of $55 \mathrm{~g} \cdot \mathrm{l}^{-1}$. The yield of citric acid was $50 \%$ and glucose utilization was $73.3 \%$ at an optimum $\mathrm{pH}$ of 6.5 . They found that addition of $4 \%$ methanol causes the increase of citric acid concentration from 55 to $90 \%$.

The production techniques, operating conditions, and parameters most effecting the biochemical pathways and synthesis of the citric acid have been studied by Vandenberg et al. [8]. The authors highlighted the main applications, current demand for the product and available manufacturing processes in the industry.

A review on citric acid production has been described by Angumeenal et al. [9]. The authors have discussed the fermentation tool, which produces the CA by less expensive renewable substrates. They also suggested that Aspergillus and Candia are the best species strains to manufacture the acid.

The statistical approach for the optimization of citric acid in the presence of filamentous fungus developed using the sweet potato and the optimal operational conditions obtained by using central composition design of RSM method were investigated by Betiku et al. [10]. From the statistical method, the highest citric acid concentration of $83.01 \mathrm{~g} \cdot \mathrm{l}^{-1}$, the concentration of sweet potato starch hydroxylate of $153.77 \mathrm{~g} \cdot \mathrm{l}^{-1}$, $\mathrm{NH}_{4} 2 \mathrm{HPO}_{4}$ of $3.55 \mathrm{~g} \cdot \mathrm{l}^{-1}, \mathrm{KH}_{2} \mathrm{PO}_{4}$ of $2.58 \mathrm{~g} \cdot \mathrm{l}^{-1}$, and $\mathrm{pH}$ of 6.0 were found for the 8 days of operation.

The citric acid has been produced by Artocarpus heterophyllus, an economical substrate using the fermentation operation [11]. The experiments were carried out and maximum concentration of citric acid was $73 \mathrm{~g} \cdot \mathrm{l}^{-1}$ after $48 \mathrm{~h}$ of operation at $14.6 \mathrm{~mol} \cdot \mathrm{l}^{-1}$ of $\mathrm{HCl}$.

The citric acid production in the presence of date syrup as the substrate with $A$. niger has been studied by Mostafa et al. [12]. The maximum production was achieved by pre-treating date syrup with $1.5 \%$ tri-calcium phosphate to remove heavy metals. The production of citric acid using pretreated medium was $38.87 \%$. The maximum production of acid was obtained at zero concentration of calcium chloride. They claim that the date syrup was the best medium for the industrial production of citric acid.

The conventional optimization technique known as the empirical method employs one-factor-at-a-time (OFAT) procedure [13]. This method involves varying one parameter by keeping all other variables constant under specified conditions. This is mainly used for very less number of variables that most affect the process. When the number of variables is less, it is easy for the interpretation of results without the help of statistical methods [14]. However, this method is very difficult when the numbers of parameters are large to optimize the process. In addition to complexity, if there is any interaction among factors or variables, the empirical method gives less information to find out effects of exact parameters. With the help of empirical methods, optimization studies were carried out to find the most effecting parameters on the yield of the desired product. From this empirical method, the affecting input variables were identified. The empirical method reduces the task of conducting number of experiments [15].

The main aim of the present work is production of citric acid with Aspergillus Niger NCIM 705 under the optimum operating conditions of initial sucrose concentration, initial medium $\mathrm{pH}$, stirrer speed, incubation period, fermentation temperature, and oxygen flow rate.

\section{Experimental}

\section{1. $M$ aterials}

The microorganism, A. niger NCIM 705, was purchased from National Chemical Laboratory, Pune, India. The substrate sucrose and the potato dextrose agar medium containing dextrose $\left(20 \mathrm{~g} \cdot \mathrm{l}^{-1}\right)$, yeast extract $\left(0.1 \mathrm{~g} \cdot \mathrm{l}^{-1}\right)$ and agar-agar $\left(20 \mathrm{~g} \cdot \mathrm{l}^{-1}\right)$; growth medium consisting of glucose, $\mathrm{NH}_{4} \mathrm{NO}_{3}, \mathrm{MgSO}_{4} \cdot 7 \mathrm{H}_{2} \mathrm{O}, \mathrm{KH}_{2} \mathrm{PO}_{4}$, $\left(\mathrm{NH}_{4}\right) \mathrm{SO}_{4}, \mathrm{Fe}\left(\mathrm{SO}_{4}\right)_{2} \cdot 24 \mathrm{H}_{2} \mathrm{O}, \mathrm{ZnSO}_{4} \cdot 7 \mathrm{H}_{2} \mathrm{O}$, phenolphthalein indicator, $0.1 \mathrm{~N} \mathrm{NaOH}$ for citric acid estimation and dinitro salicylic acid for sucrose estimation were procured from M/s Hichem Services, Warangal, India. Autoclave for sterilization of medium and fermenter, laminar flow chamber for inoculation and the glass fermentor procured from M/s Scigenics India Ltd make were used for experiments and cultivation.

\subsection{Plackett-Burman Design}

In any commercial process, the optimization of selected parameters is important due to the economical feasibility as well as the practical feasibility of operation. In the fermentation process, the most important parameters also have to be optimized with the help of the statistical methods and analysis [16]. Plackett-Burman designs at two level fractional factorial designs are for studying $k$ number of runs, where $k=n-1$ runs. Here, $n$ is a multiple of 4 and $k$ is the number of variables. The design considers the main effects of the variables but not their interactive effects [17].

The Plackett-Burman design can be represented by the first-order polynomial equation (Eq. 1):

$$
Y=\beta \mathrm{O}+\sum_{i=1}^{\mathrm{n}} \beta_{i} x_{i}
$$

where $Y$ represents the response in the model; $\beta$ o is the constant; $\beta_{i}$ is the linear coefficient; $x_{i}$ is the variable and $n$ is the number of parameters. Each variable is represented in two levels, high (+) and low (-).

The effect of each variable can be evaluated by

Eq. 2:

$$
E_{(x i)}=\left(\sum_{m i+}-\sum_{m i-}\right) / N
$$


where $E_{(x i)}$ is the tested variable; $\sum_{m i+}$ is the summation of the response value at a high level; $\sum_{m i}$ is the summation of the response value at low level and $N$ is the number of experiments.

In the present study citric acid yield has been the response or dependent variable, and the number of independent variables was eleven: initial sucrose concentration, methanol concentration, inoculum density, initial medium $\mathrm{pH}$, spore age, stirrer speed, incubation period, fermentation temperature, particle size distribution, oxygen flow rate, and moisture content. Twelve experiments were recommended for nine variables by Plackett-Burman designs [18]. Twelve experiments were conducted accordingly to evaluate the degree of influence of each variable on the citric acid yield. The variables with confidence levels greater than $95 \%$ are considered to strongly influence the citric acid yield. From this design, it has been found that six most significant variables are initial sucrose concentration, initial medium $\mathrm{pH}$, stirrer speed, incubation period, fermentation temperature, and oxygen flow rate, which strongly influence the citric acid yield.

\subsection{Experimental Setup and Procedure}

A pure culture of A. niger NCIM 705 was procured and preserved in refrigerator by periodic subculture on potato dextrose agar medium. A fermentor of 1.21 capacity was equipped with standard control and instrumentation as shown in Fig. 1. The fermentor equipped with impeller of three blades and two $500 \mathrm{ml}$ bottles are provided for addition of acid and base, and $\mathrm{pH}$ controller was used to control the $\mathrm{pH}$. The temperature indicator was used to measure temperature in the fermentor and the cooling water supplied to fermentor to maintain uniform temperature. The fermentor was cleaned with water and sterilized for $20 \mathrm{~min}$ in an autoclave. This sterilized fermentor was placed in the main assembly to which water and $\mathrm{O}_{2}$ were supplied through the tube connections. $25 \%$ of sucrose solution were taken, $35 \mathrm{ml}$ of $1 \mathrm{~N} \mathrm{H}_{2} \mathrm{SO}_{4}$ was added to solution and then it was boiled for half an hour. Then the mixture was cooled and neutralized with lime water for $12 \mathrm{~h}$ for clarification. The clear supernatant liquid was diluted to $15 \%$ sucrose level. The solution and growth medium were sterilized, inoculated and the mixture was kept in an incubator for $24 \mathrm{~h}$. The prepared culture was poured into the fermentor in the first run and thereafter the fermentor was put into operation for 7 days for batch operation.

\subsection{Analysis}

The samples were collected from the fermentor periodically for every $24 \mathrm{~h}$ and analysed for sucrose, biomass and citric acid using standard analytical methods $[19,20]$. Citric acid concentration was measured by titration with $0.1 \mathrm{~N} \mathrm{NaOH}$ phenolphthalein indicators. The amount of acetic was determined from $N_{1} V_{1}=N_{2} V_{2}$ formula. DNS method was used to measure the concentration of sucrose. The colour intensity was measured by single beam UV scanning spectrophotometer (Systronics made, model-117). One drop of concentrated $\mathrm{HCl}$ solution was added to $1 \mathrm{ml}$ of the sucrose solution in a flask and heated to $363 \mathrm{~K}$ for $5 \mathrm{~min}$ to allow hydrolysis. Then three drops of $5 \mathrm{~N} \mathrm{KOH}$ solution were added to neutralize the acid. Formation of red brown colour, which represents the presence of reducing sugars, was observed. The colour intensity was measured at $220 \mathrm{~nm}$ with the DNS reagent. The colour intensity was found to be proportional to the concentration of sugar.

Biomass was estimated by using a centrifuge. $1 \mathrm{ml}$ of the sample was taken from the fermentor with pipette into a micro centrifuge test tube of $1.5 \mathrm{ml}$ capacity. Then the sample was kept inside a centrifuge. The speed and temperature of centrifuge were maintained at $200 \mathrm{rpm}$ and at $303 \mathrm{~K}$, respectively, for $10 \mathrm{~min}$. Biomass was collected from the samples withdrawn, discarding the solution. The test tube was kept in a hot oven for about $10 \mathrm{~min}$, cooled and then the final weight was measured. The difference between the initial and final weights gives the biomass.

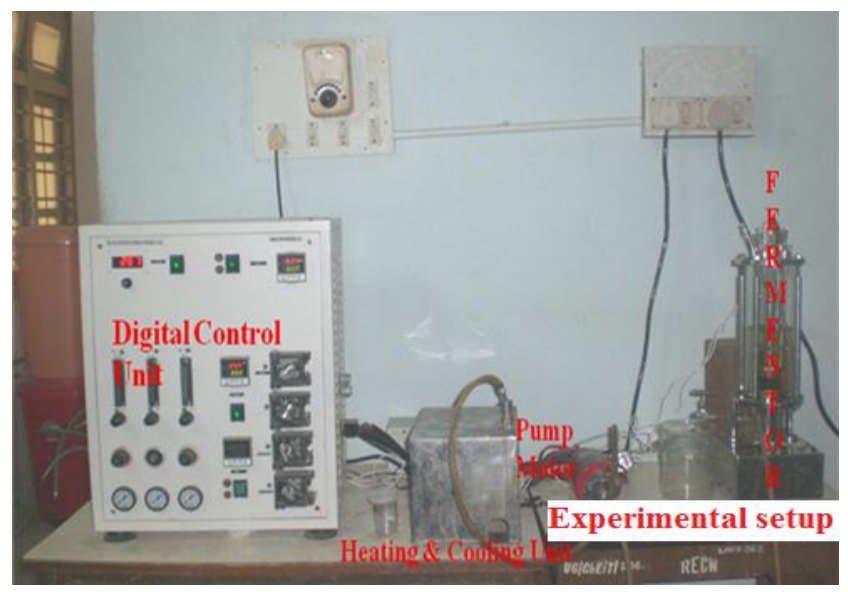

Fig. 1. Batch fermentation set-up

\section{Results and Discussion}

\subsection{Design of Experiments}

From the literature review, eleven variables namely initial sucrose concentration, methanol concentration, inoculums density, initial medium $\mathrm{pH}$, spore age, stirrer speed, incubation period, fermentation temperature, particle size distribution, oxygen flow rate, and moisture content were found to be governing citric acid bioprocess. Among the process variables identified, the significant factors were assessed using Plackett-Burman Designs 
(PBD). In the present study, citric acid is the response variable, the number of variables are eleven $(v=11), E_{(x i)}$ represents the tested eleven variables and the number of experiments are twelve $(n=12)$. Twelve experiments were recommended for eleven variables by PlackettBurman designs. The experiments were conducted accordingly to evaluate the degree of influence of each variable on the yield of citric acid. The range considered for the variables is shown in Table 1.

All trials have been conducted for three times and the citric acid produced was treated as the response. The main effect of each variable was calculated as the difference between the averages of measurements made at the high (+) and low (-) settings of that factor. The change in the concentration of citric acid with respect to each set of variables during fermentation have been determined and recorded as shown in Table 2.

The Pareto analysis is one of the best statistical methods for quick decision on the selected parameters. This method is used for reducing the number of experimental tasks to produce significant overall effect.
The Pareto chart shown in Fig. 2 explains the contributory effect of each variable on citric acid biosynthesis. The bars in orange colour show positive and significant effects and those in blue indicate negative and insignificant effects.

Out of eleven variables, initial sucrose concentration, initial medium $\mathrm{pH}$, stirrer speed, incubation period, fermentation temperature, and Oxygen flow rate were determined to be significant factors using PBD.

Initial optimization studies were carried out for these six variables experimentally in two rounds on onefactor-at-a-time (OFAT) basis to obtain preliminary information on local optimal parameters. Thirty six experiments were conducted in $1^{\text {st }}$ round as per OFAT. The range of the variables for $2^{\text {nd }}$ round of experiments was reduced based on $1^{\text {st }}$ round local optimals and thirty more experiments were conducted. After $2^{\text {nd }}$ round of experiments, the effect of each variable on citric acid yield was discussed critically with a series of plots. Figs. 3-8 show how sucrose consumed, biomass generated and citric acid produced are affected by varying each factor.

Table 1

The lower and upper limits of the variables

\begin{tabular}{|c|c|c|c|c|}
\hline S. No & Parameter & Units & Low level & High level \\
\hline 1 & initial sucrose concentration & $\mathrm{g} \cdot \mathrm{l}^{-1}$ & 80 & 200 \\
\hline 2 & methanol concentration & $\mathrm{v} / \mathrm{w} \%$ & 3 & 4 \\
\hline 3 & inoculum density & $\mathrm{spore} / \mathrm{ml}$ & $10^{4}$ & $10^{9}$ \\
\hline 4 & initial medium $\mathrm{pH}$ & - & 5.0 & 7.0 \\
\hline 5 & spore age & $\mathrm{days}$ & 4 & 6 \\
\hline 6 & stirrer speed & days & 170 & 310 \\
\hline 7 & incubation period & $\mathrm{K}$ & 301 & 10 \\
\hline 8 & fermentation temperature & $\mu \mathrm{m}$ & 0.4 & 305 \\
\hline 9 & particle size distribution & $1 \cdot \mathrm{min}^{-1}$ & 0.5 & 1 \\
\hline 10 & oxygen flow rate & $\mathrm{v} / \mathrm{w} \%$ & 60 & 2.5 \\
\hline 11 & moisture content & & 85 \\
\hline
\end{tabular}

Table 2

Experimental results for Plackett-Burman design

\begin{tabular}{|c|c|c|c|c|c|c|c|c|c|c|c|c|}
\hline Run & $\begin{array}{c}\text { Initial } \\
\text { sucroce } \\
\text { concent } \\
\text { ration, } \\
\mathrm{g} \cdot \cdot^{-1}\end{array}$ & $\begin{array}{c}\text { Methanol } \\
\text { concent } \\
\text { ration, } \\
\mathrm{g} \cdot l^{-1}\end{array}$ & $\begin{array}{c}\text { Inoculum } \\
\text { density, } \\
\text { spore/ml }\end{array}$ & $\begin{array}{c}\text { Initial } \\
\text { medium } \\
\mathrm{pH}\end{array}$ & $\begin{array}{c}\text { Spore } \\
\text { age, } \\
\text { days }\end{array}$ & $\begin{array}{c}\text { Stirrer } \\
\text { speed, } \\
\mathrm{rpm}\end{array}$ & $\begin{array}{c}\text { Incuba } \\
\text { tion } \\
\text { period, } \\
\text { days }\end{array}$ & $\begin{array}{c}\text { Fermenta } \\
\text { tion } \\
\text { tempera } \\
\text { ture, } \mathrm{K}\end{array}$ & $\begin{array}{c}\text { Particle } \\
\text { size } \\
\text { distribu } \\
\text { tion, } \\
\mu \mathrm{m}\end{array}$ & $\begin{array}{c}\mathrm{O}_{2} \\
\text { flow } \\
\text { rate, } \\
1 \cdot \mathrm{min}^{-1}\end{array}$ & $\begin{array}{c}\text { Moisture } \\
\text { content, } \\
\mathrm{v} / \mathrm{w} \%\end{array}$ & $\begin{array}{c}\text { Citric } \\
\text { acid } \\
\text { concent } \\
\text { ration, } \\
\mathrm{g} \cdot \mathbf{l}^{-1}\end{array}$ \\
\hline 1 & 200 & 3 & $10^{9}$ & 7 & 6 & 170 & 1 & 301 & 1 & 0.5 & 85 & 60 \\
\hline 2 & 200 & 7 & $10^{4}$ & 5 & 4 & 310 & 1 & 305 & 1 & 0.5 & 85 & 25 \\
\hline 3 & 80 & 7 & $10^{9}$ & 5 & 6 & 310 & 10 & 301 & 0.4 & 0.5 & 85 & 55 \\
\hline 4 & 200 & 7 & $10^{4}$ & 7 & 6 & 310 & 1 & 301 & 0.4 & 2.5 & 60 & 40 \\
\hline 5 & 80 & 3 & $10^{4}$ & 7 & 4 & 310 & 10 & 301 & 1 & 2.5 & 85 & 36 \\
\hline 6 & 80 & 3 & $10^{4}$ & 5 & 4 & 170 & 1 & 301 & 0.4 & 0.5 & 60 & 40 \\
\hline 7 & 200 & 7 & $10^{9}$ & 5 & 4 & 170 & 10 & 301 & 1 & 2.5 & 60 & 67 \\
\hline 8 & 200 & 3 & $10^{4}$ & 5 & 6 & 170 & 10 & 305 & 0.4 & 2.5 & 85 & 35 \\
\hline 9 & 80 & 3 & $10^{9}$ & 5 & 6 & 310 & 1 & 305 & 1 & 2.5 & 60 & 45 \\
\hline 10 & 80 & 7 & $10^{9}$ & 7 & 4 & 170 & 1 & 305 & 0.4 & 2.5 & 85 & 38 \\
\hline 11 & 200 & 3 & $10^{9}$ & 7 & 4 & 310 & 10 & 305 & 0.4 & 0.5 & 60 & 44 \\
\hline 12 & 80 & 7 & $10^{4}$ & 7 & 6 & 170 & 10 & 305 & 1 & 0.5 & 60 & 57 \\
\hline
\end{tabular}




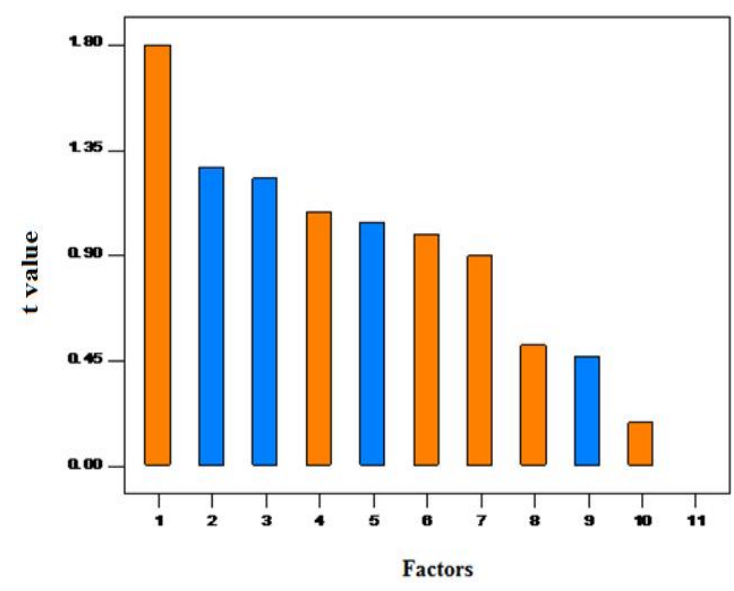

Fig. 2. Pareto chart showing effects of variables (factors) on citric acid accumulation

\subsection{Effect of Initial Sucrose Concentration}

Fig. 3 shows the effect of initial sucrose concentrations varying from 140 to $180 \mathrm{~g} \cdot \mathrm{l}^{-1}$ on citric acid accumulation using A. niger NCIM 705. The other conditions are $\mathrm{pH} 6.5$, stirrer speed $240 \mathrm{rpm}$, incubation period 8 days, temperature $303 \mathrm{~K}$, and oxygen flow rate $21 \cdot \mathrm{min}^{-1}$. From Fig. 3, it is observed that maximum citric acid concentration is found to be $60.58 \mathrm{~g} \cdot \mathrm{l}^{-1}$ at the concentration of initial sucrose of $170 \mathrm{~g} \cdot \mathrm{l}^{-1}$. The consumption of sucrose and dry mycelial weight were found to be 59.8 and $47.3 \mathrm{~g} \cdot \mathrm{l}^{-1}$, respectively. From the experiment, it can be observed that the initial sucrose concentration is influencing the amount of citric acid produced by $A$. niger NCIM 705. When the sucrose concentration varied from140 to $170 \mathrm{~g} \cdot \mathrm{l}^{-1}$, citric acid formation increased, however beyond $170 \mathrm{~g} \cdot \mathrm{l}^{-1}$ citric acid formation is decreasing due to the overgrowth of the mycelium. Overgrowth of mycelium causes the increasing of the viscosity of the medium, which was also observed [21]. Pazouki et al. [22] have observed that sugar concentration more than 16-18\% causes higher amount of residual sugars, making the process more uneconomical. Sugar concentration below optimal level leads to less yields of citric acid.

\subsection{Effect of Initial Medium pH}

The change in culture $\mathrm{pH}$ causes the microbial metabolic activities due to the secretion of organic acids. The desirable or favourable $\mathrm{pH}$ maintained in the fermentation process is extremely important for the production of citric acid. The other conditions are as follows: initial sucrose concentration $170 \mathrm{~g} \cdot \mathrm{l}^{-1}$, stirrer speed $240 \mathrm{rpm}$, incubation period 8 days, temperature $303 \mathrm{~K}$, and oxygen flow rate $21 \cdot \mathrm{min}^{-1}$. Fig. 4 shows the effect of initial medium $\mathrm{pH}$ in the range of 5.0-7.0 on the production of citric acid. The sucrose consumed, dry biomass generated and maximum citric acid produced were found to be $59.8,47.3$ and $60.58 \mathrm{~g} \cdot \mathrm{l}^{-1}$, respectively, when the initial $\mathrm{pH}$ was set at 6.5. The value of $\mathrm{pH}$ lower than 6.5 in sucrose medium was found to be inhibiting for the growth of $A$. niger, causing the decrease in citric acid concentration. This is due to the toxic nature of ferrocyanide ions decreasing the growth of mycelium in the medium [23]. At higher initial $\mathrm{pH}$ value, it leads to the by-products accumulation, such as oxalic and gluconic acids [24]. Hence, the decrease in citric acid formation was observed when $\mathrm{pH}$ was increased beyond 6.5.

\subsection{Effect of Stirrer Speed}

Fig. 5 shows the effect of stirrer speeds on citric acid formation by A. niger NCIM 705. The stirring speed of the fermentor was maintained in the range of 210 $250 \mathrm{rpm}$. The other conditions are as follows: initial sucrose concentration $170 \mathrm{~g} \cdot \mathrm{l}^{-1}, \mathrm{pH} 6.5$, incubation period 8 days, temperature $303 \mathrm{~K}$, and oxygen flow rate $21 \cdot \mathrm{min}^{-1}$. When the stirring speed increased up to $240 \mathrm{rpm}$, the citric acid concentration was found to be increasing. However, as the stirring speed was maintained higher than $240 \mathrm{rpm}$, the concentration of citric acid was noticed to decrease. The amount of citric acid produced, biomass generated and sucrose consumed were found to be maximum at $240 \mathrm{rpm}$, that maintains proper aeration rate to supply the oxygen. The maximum citric acid, biomass generated and sucrose consumed is $65.56,46.11$ and $87.1 \mathrm{~g} \cdot \mathrm{l}^{-1}$, respectively, at $240 \mathrm{rpm}$. Minimum stirrer speed is required to enhance the mechanical forces on the fungal cells. Overstirring causes the damage of A. niger, which results in low biomass production $[25,26]$.

\subsection{Effect of Incubation Period}

Fig. 6 shows the effect of incubation period on citric acid concentration. The incubation period was 2 10 days. The other conditions are as follows: initial sucrose concentration $170 \mathrm{~g} \cdot \mathrm{l}^{-1}, \mathrm{pH} 6.5$, stirrer speed $240 \mathrm{rpm}$, temperature $303 \mathrm{~K}$, and oxygen flow rate $21 \cdot \mathrm{min}^{-1}$. From Fig. 6, it is observed that the production of citric acid was initiated after overcoming the lag phase and then it reached maximum concentration of $66.66 \mathrm{~g} \cdot \mathrm{l}^{-1}$ ( 8 days). The maximum sucrose consumption and biomass generation after 8 days of incubation time were found to be 87.32 and $45.76 \mathrm{~g} \cdot \mathrm{l}^{-1}$, respectively. Further increase in incubation time beyond 8 days did not enhance citric acid formation due to decreasing activity of fungi as well as depletion of the sugar contents in the medium [27]. It was also found a slight increase in biomass but decrease in citric acid. 


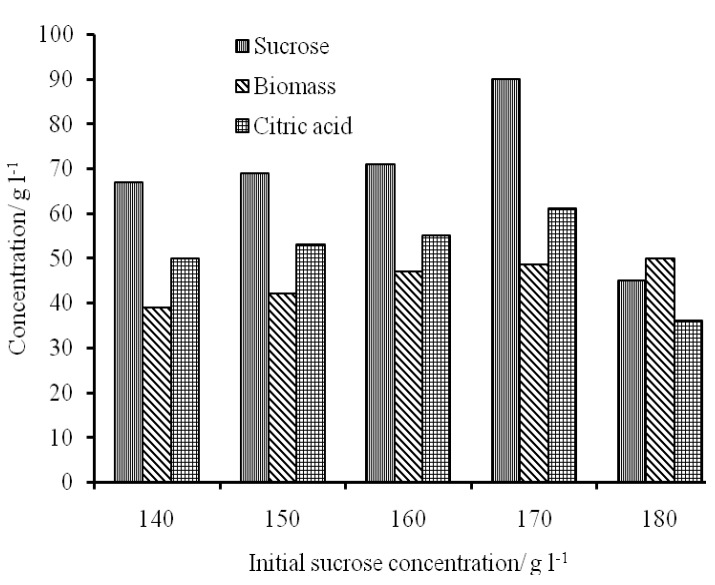

Fig. 3. Variation of sucrose, biomass and citric acid concentrations with initial sucrose concentration

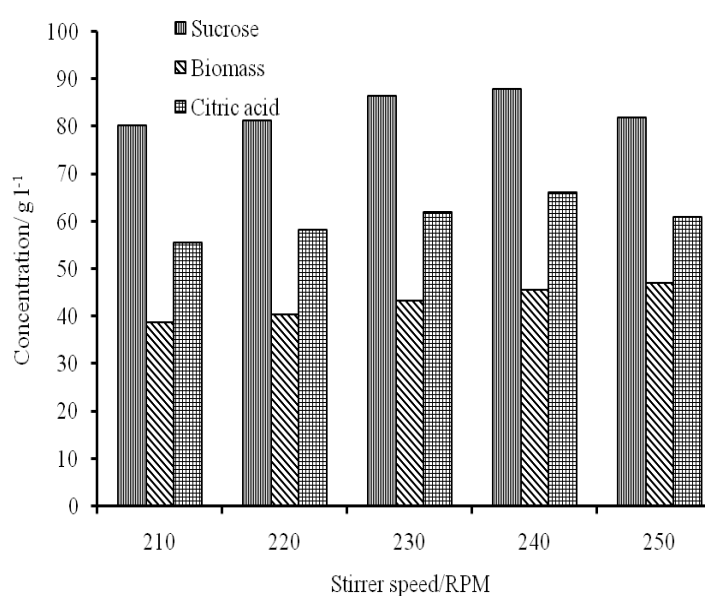

Fig. 5. Variation of sucrose, biomass and citric acid concentrations with stirrer speed

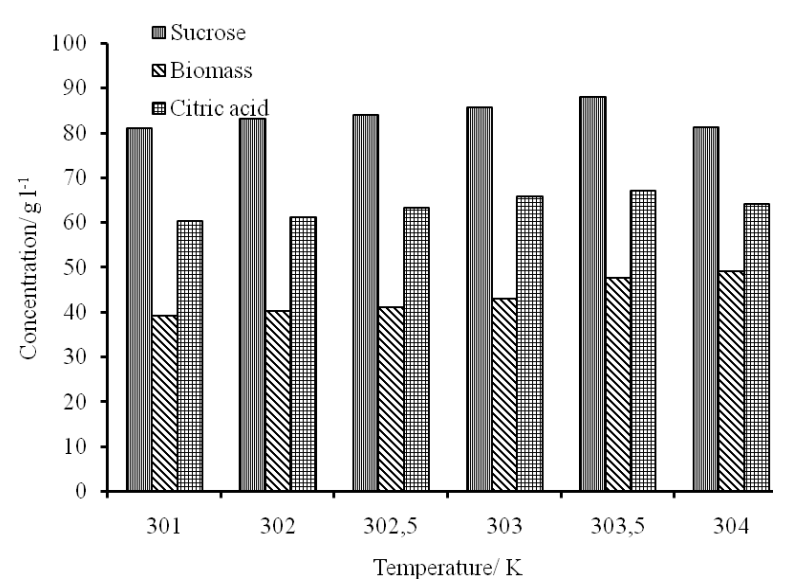

Fig. 7. Variation of sucrose, biomass and citric acid concentrations with fermentation temperature

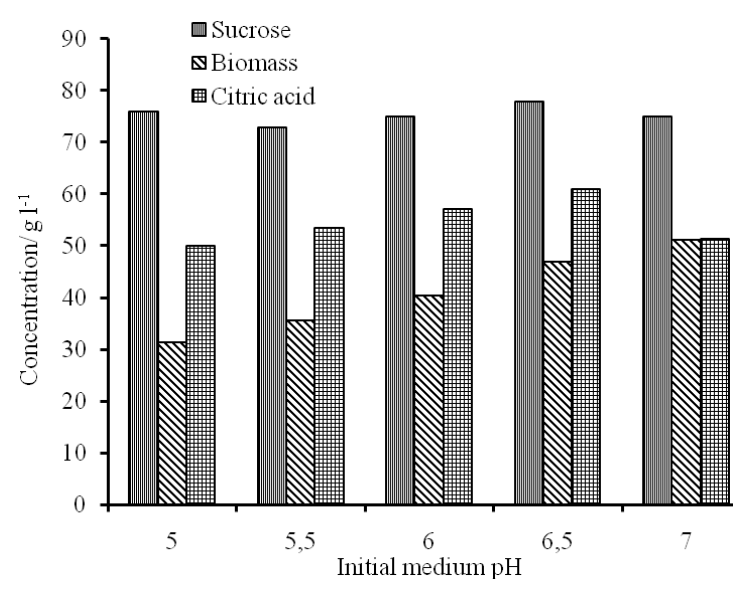

Fig. 4. Variation of sucrose, biomass and citric acid concentrations with initial medium $\mathrm{pH}$

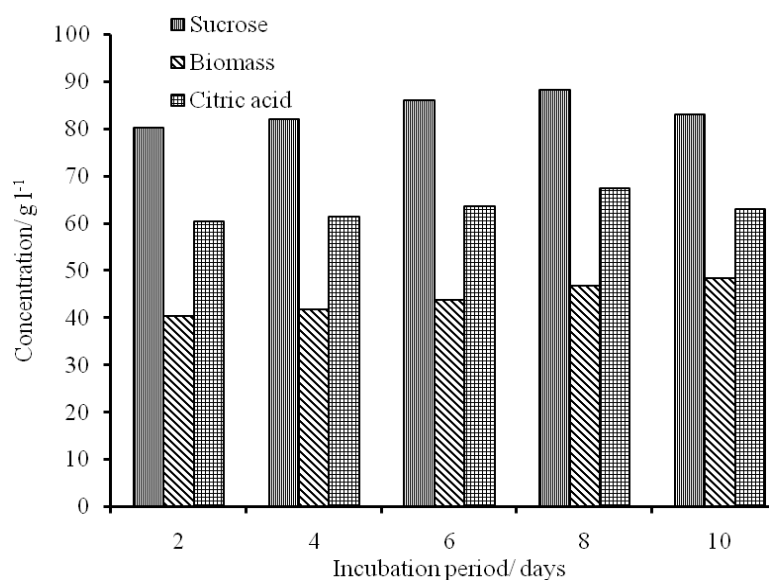

Fig. 6. Variation of sucrose, biomass and citric acid concentrations with incubation period

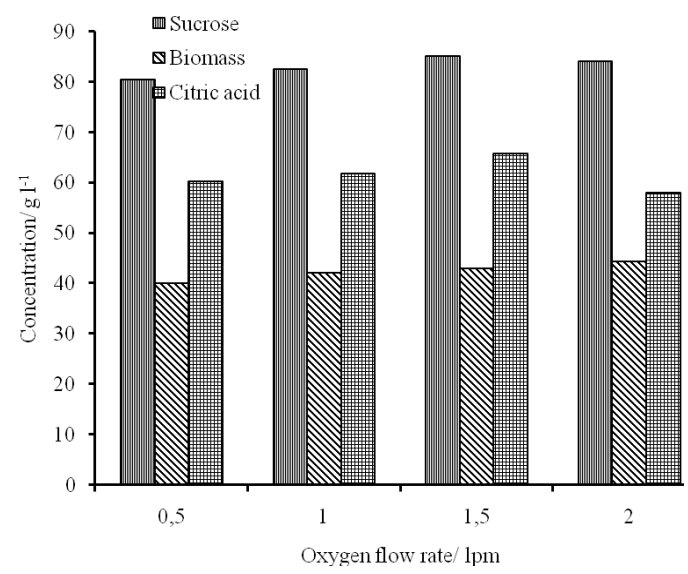

Fig. 8. Variation of sucrose, biomass and citric acid concentrations with oxygen flow rate 


\subsection{Effect of Fermentation Temperature}

Fig. 7 shows the effect of fermentation temperature on production of citric acid by A. niger NCIM 705 in batch fermentor. The fermentor temperature is maintained in the range of $301-305 \mathrm{~K}$. The other conditions are as follows: initial sucrose concentration $170 \mathrm{~g} \cdot \mathrm{l}^{-1}, \mathrm{pH} 6.5$, stirrer speed $240 \mathrm{rpm}$, incubation period 8 days, and oxygen flow rate $21 \cdot \mathrm{min}^{-1}$. Citric acid maximum amount of $66.28 \mathrm{~g} \cdot \mathrm{l}^{-1}$ was obtained when the temperature of the medium was maintained at $303.5 \mathrm{~K}$. The sucrose consumption and dry mycelial weight (biomass) were found to be maximum 87.24 and $47.39 \mathrm{~g} \cdot \mathrm{l}^{-1}$, respectively, at $303.5 \mathrm{~K}$.

The temperature of fermentation shows profound effect on citric acid formation. At low medium temperatures enzyme activity is low, hence the formation of acid is less. However, when the temperature of medium was increased beyond $303.5 \mathrm{~K}$, formation of citric acid was decreased.

\subsection{Effect of Oxygen Flow Rate}

Fig. 8 shows the effect of oxygen flow rate on biosynthesis of citric acid in $0.5-2.5 \mathrm{lpm}$ range. The other conditions are initial sucrose concentration $170 \mathrm{~g} \cdot \mathrm{l}^{-1}, \mathrm{pH}$ 6.5 , stirrer speed $240 \mathrm{rpm}$, incubation period 8 days and temperature $303 \mathrm{~K}$. The agitation intensity and oxygen flow rate are interrelated and show direct influence on the amount and rate of citric acid formation. The maximum amount of citric acid $\left(65.66 \mathrm{~g} \cdot \mathrm{l}^{-1}\right)$, biomass $\left(43.30 \mathrm{~g} \cdot \mathrm{l}^{-1}\right)$ and sucrose consumption $\left(84.20 \mathrm{~g} \cdot \mathrm{l}^{-1}\right)$ were noticed at the speed of $240 \mathrm{rpm}$ and aeration rate of $1.5 \mathrm{lpm}$.

When the aeration flow rate increased beyond the $1.5 \mathrm{lpm}$, the citric acid formation was decreased. The reason for decreasing of the acid formation is that at high flow rates the dissolved oxygen levels decreased. Hence, a proper aeration and agitation is required for supplying oxygen and maintaining required DO levels in the fermentor.

\section{Conclusions}

For high productivity and economic operation of the commercial scale citric acid plants, meticulous optimization of citric acid processes is vital. Hence, the governing variables of citric acid production were collected, screened for significant variables using Plackett Burman designs and optimized using OFAT. The optimization studies on significant variables by onefactor-at-a-time method reported the local optimum conditions to be as follows: initial sucrose concentration $180 \mathrm{gl}^{-1}$, initial medium $\mathrm{pH} 6.5$, stirrer speed $250 \mathrm{rpm}$, incubation period 6 days, fermentation temperature $303 \mathrm{~K}$, and oxygen flow rate $2.0 \mathrm{lpm}$.

\section{Acknowledgements}

Financial assistance from DST, India through the grant SR/FST/College/2014 is gratefully acknowledged. Providing the experimental facilities for the present research by the Director of the Department of Chemical Engineering, National Institute of Technology Warangal, Telangana, India is heartfully acknowledged.
List of abbreviations and symbols
E tested variable
$k \quad$ run number
$m i+$ response at high value
$\mathrm{mi}^{-}$response at lower value
$n \quad$ run number
$N \quad$ number of experiments
$Y \quad$ citric acid yield (response)

\section{References}

[1] Wehmer C.: Bulln. Soc. Chem. Fr., 1983, 9, 728.

[2] Kursat O., Gokhan D., Ahmet Y.: J. Food Eng., 2005, 70, 518. https://doi.org/10.1016/j.jfoodeng.2004.10.006

[3] Crolla A., Kennedy K.: J. Biotechnol., 2004, 110, 73.

https://doi.org/10.1016/j.jbiotec.2004.01.007

[4] Kamzolova S, Shishkanova N., Murgunov I., Finoginova T.:

FEMS Yeast Res., 2003, 3, 217. https://doi.org/10.1016/S1567-

1356(02)00188-5

[5] Hossain M., Brooks J., Maddox I.: Appl. Microbiol. Biotechnol., 1984, 19, 393. https://doi.org/10.1007/BF00454376

[6] Xu D., Madrid C., Rohr M., Kubicek C.: Appl. Microb.

Biotechnol., 1989, 30, 553. https://doi.org/10.1007/BF00255358

[7] Roukas T., Kotzekidou P.: Enzyme Microb. Technol., 1997, 21,

273. https://doi.org/10.1016/S0141-0229(97)00041-0

[8] Vandenberghe L., Rodrigues C., de Carvalho J. et al.:

Production and Application of Citric Acid [in:] Current

Developments in Biotechnology and Bioengineering: Production,

Isolation and Purification of Industrial Products. Elsevier 2016, $557-$

575. https://doi.org/10.1016/B978-0-444-63662-1.00025-7

[9] Angumeenal A., Venkappayya D.: LWT - Food Sci Technol.

2013, 50, 367. https://doi.org/10.1016/j.lwt.2012.05.016

[10] Betiku E., Adesina O.: Biomass Bioenerg., 2013, 55, 350.

https://doi.org/10.1016/j.biombioe.2013.02.034

[11] Angumeenal AR, Venkappayya D. LWT Food Sci. Technol.

2005, 38, 89. https://doi.org/10.1016/j.lwt.2004.04.014

[12] Mostafa Y., Alamri S.: Saudi J. Biol. Sci., 2012, 19, 241.

https://doi.org/10.1016/j.sjbs.2012.01.004

[13] Ooijkaas L., Wilkinson E., Tramper J., Buitelaar R.:

Biotechnol. Bioeng., 1999, 64, 92.

https://doi.org/10.1002/(SICI)1097-0290(19990705)64:1<92::AID-

BIT10>3.0.CO;2-8

[14] Wen Z., Chen F.: Biotechnol. Bioeng., 2001, 75, 159.

https://doi.org/10.1002/bit.1175

[15] Li C., Bai J., Li W., Cai Z.: Ouyang F. Biotechnol. Prog., 2001, 17, 366. https://doi.org/10.1021/bp000167w

[16] Duta F., de Franca F., Lopez L.-M: Electron. J. Biotechnol., 2006, 9, 391. https://doi.org/10.2225/vol9-issue4-fulltext-7

[17] Plackett R., Burman J.: Biometrika, 1946, 33, 305.

https://doi.org/10.1093/biomet/33.4.305

[18] Montgomery D.: Design and Analysis of Experiments, $6^{\text {th }}$ edn. John Wiley \& Sons 2005, Ch. 11. 
[19] Marrier J., Boulet M.: J. Dairy Sci., 1958, 41, 1683. https://doi.org/10.3168/jds.S0022-0302(58)91152-4

[20] Miller G.: Anal. Chem., 1959, 31, 426.

https://doi.org/10.1021/ac60147a030

[21] Mattey M., Allan A.: Biochem. Soc. Trans., 1990, 18, 1020. https://doi.org/10.1042/bst0181020

[22] Pazouki M., Felse P., Sinha J., Panda T.: Bioproc. Eng., 2000, 22, 353. https://doi.org/10.1007/PL00009115

[23] Pessoa D., Diasde C., Angela C.: Revista de Microbiologia, 1982, 13, 225.

[24] Shadafza D., Ogawa T., Fazeli A.: Hakko Kogaku Zasshi, 1976, 54, 65.

[25] Dawson M., Maddox I., Brooks J.: Enzym. Microb. Technol., 1986, 9, 37. https://doi.org/10.1016/0141-0229(86)90008-6

[26] Sanjay K., Sharma P.: J. Microb., 1994, 23, 211.

[27] Arzumanov T., Shishkanova N., Finogenova T.: Appl.

Microbiol. Biotechnol., 2000, 53, 525.

https://doi.org/10.1007/s002530051651

Received: September 18, 2017 / Revised: November 02, 2017 / Accepted: January 28, 2018

\section{ОПТИМІЗАЦІЯ БІОСИНТЕЗУ ЛИМОННОЇ КИСЛОТИ ЗА ДОПОМОГОЮ МОНОТЕТИЧНОГО АНАЛІЗУ ЧИННИКІВ}

Анотація. Проведено оцінювання чинників процесу біосинтезу лимонної кислоти, та проаналізовано ӥх вплив на результат процесу. Встановлено, щчо такі чинники, як початкова конщентрачія сахарози, конщентраџія метанолу, конщентрачія інокуляту, рН вихідного середовища, вірогідність спору, швидкість обертання мішалки, період інкубаиії, температура бродіння, розмір частинок, швидкість потоку кисню та вологість мають значний вплив на прочес. 3 використанням експериментального дизайну Плакетта-Бурмана з одинадияти чинників визначено ті, які мають найбільший вплив на процес: початкова концентрачія сахарози, рН вихідного середовища, швидкість обертання мімалки, інкубаиійний період, температура бродіння та витрата кисню. 3 а допомогою монотетичного аналізу експериментально підтверджений та критично оцінений вплив чинників на вихід лимонної кислоти.

Ключові слова: лимонна кислота, сахароза, період інкубаиії, ферментачія, оптимізація, монотетичний аналіз. 